\title{
Reassessing 1960 s philosophy of the curriculum
}

\author{
John White* \\ Institute of Education, U niversity of L ondon, U K
}

A prominent thesis of British philosophy of education in the 1960s was that the pursuit of different forms of knowledge is central to education. The fact that the thesis is difficult to justify philosophically raises questions about its historical provenance. The idea of such a curriculum can be traced back through the history of the middle-class curriculum to the education of dissenters in the eighteenth century and further back still to sixteenth-century Ramism. There are indications that some leading 1960s philosophers of education were affected, positively or negatively, by these older religious ideas, but it is not clear how much should be made of this.

\section{Introduction}

When I came into philosophy of education in the 1960s, a coreidea was that education, or liberal education, isessentially to do with the pursuit of various kinds of propositional knowledge for non-instrumental reasons. Paul Hirst argued this in H irst (1974b); Richard Peters in Peters (1966, chapter 5); and both authors together (in $\mathrm{H}$ irst \& Peters, 1970). T hese arguments are well known and do not need elaborating here.

There have been many kinds of critique of these positions. The one that has always interested me (see White, 1973, chapters 2 and 6; 1990, chapter 7) and still does is: why go for this position in the first place? $\mathrm{H} \mathrm{ow}$, if at all, can it be justified?

Several sorts of justification were provided in those days, from the 'transcendental' arguments used by Peters (1966, pp. 163-165) and $\mathrm{H}$ irst (1965b, pp. 125-126) to D ownie, Loudfoot and T elfer's (1974, p. 50) appeal to intuition. The suggestion in these arguments tended to be that there is something odd about even raising the question 'Why pursue knowledge?': for asking the question presupposes a commitment to this pursuit and/or it carries a false presumption that the claim requires further grounding. T he challenges to the two positions are also well-known and here

\footnotetext{
*School of Educational Foundations and Policy Studies, Institute of Education, U niversity of London, UK. E mail: j.white@ioe.ac.uk
} 
I will take their cogency as read (see White, 1973, pp. 11-13, 78-82). T heir upshot has been to insist that the question cannot be just spirited away like this. There are many alternative candidates for central aims of education and it cannot be taken for granted that the pursuit of various types of theoretical understanding for noninstrumental reasons wins out over more practical pursuits, personal development, citizenship or promoting a strong economy.

Even the critics of the theory shared a wider commitment with its proponents. D earden (1968), White (1973), Barrow (1976) and D ownie et al. (1974) produced other justifications of curriculum activities. But Dearden, White, Barrow and D ownie et al. took for granted something about the content of those curriculum activities: that disciplined forms of thought-e.g., in science, mathematics, history, the arts, philosophy-should be at or near their centre. Crudely, for there were variations in all these positions, they took over something like the curriculum content of $\mathrm{H}$ irst and Peters and appeared to see their main philosophical task as seeking to furnish it with a more adequate rationale than those two authors were perceived to have done.

B ritish sociologists of education of that period gave the philosophers of education a hard time - notably M ichael Y oung (1971, chapter 1), who wrote that their position:

... appears to be based on an absolutist conception of a set of distinct forms of knowledge which correspond closely to the traditional areas of the academic curriculum and thus justify, rather than examine, what are no more than the socio-historical products of a particular time. (Y oung, 1971, p. 23)

The response of the philosophers tended to be to brush this kind of criticism aside. They said it embraced, indefensibly, a relativistic view of knowledge. Also, there was nothing in their attachment to disciplines of thought that made them root for traditional school subjects: where were modern languages in the $\mathrm{H}$ irstian scheme and its variants? Where was physical education?

$Y$ et Young's shaft was basically on target. Those on the inside of the (mainly) 'London line' saw the variations between the positions of $\mathrm{H}$ irst, Peters, Dearden, White, Barrow and D ownie et al. in terms of deep chasms between rival approaches. F rom a more distanced point of view, similarities were more perceptible than differences. If the insiders weren't arguing for a school curriculum of traditional subjects, they were certainly in favour of an idealised form of this, one which subjected most of its traditional content to philosophically defensible considerations about the nature of knowledge. I should gloss this last remark in the case of Paul $\mathrm{H}$ irst, who has made it clear in all his writings that his theory was about a 'liberal education' and not about school subjects or the school curriculum as a whole, which might contain nonintellectual elements like physical education. This said, it is still true that on his view the disciplines of knowledge were to have a central place in curriculum design.

This preconception in favour of intellectual activities tended to obscure the fact that curriculum planning has to start farther back. It should not begin by taking a certain content as central-in this case, intellectual activities-but needs to begin 
with a review of more general educational aims and with decisions based on the most defensible of these. T rue, D earden, White, Barrow and D ownie et al. discussed various aims, e.g., personal autonomy, morality and happiness. $\mathrm{H}$ irst, as we shall see below, made a connexion between the pursuit of knowledge and the good life. But none of them began with a comprehensive assessment of possible aims and then went into ways of realising the more defensible of them, without prejudice as to what the ways might be. They appeared to take it as read that intellectual pursuits were to be dominant.

\section{Puritan Origins}

From a 2005 perspective the philosophers of education of the 1960s seem to be unwitting apologists of a specific form of schooling. $M$ ichael $Y$ oung was right to call it a socio-historical product of a particular time. The curriculum they favoured was an idealised form of the broad, subject-based, intellectually-orientated, curriculum which, over the previous half century had come to dominate élite education in the new (i.e., post-1904) State secondary grammar schools and in independent schools. The 1960s were a decade in which the divisions of the post-war tripartite system were under challenge and many, especially after the L abour election victory in 1964, wanted the academic education of the grammar school to be provided for all children, not for a minority. The curricular philosophies of Peters, H irst, Barrow, D earden, D ownie et al., W hite and others can be read as theoretical elaborations of this egalitarian idea, which became increasingly realised in practice in the new comprehensive schools of that era.

What is this broad, academic curriculum which these philosophers all then took as read and which, since the coming of the $\mathrm{N}$ ational Curriculum in 1988, has become staple for the whole nation? Its origins can be traced back at least to the early eighteenth century and indeed to the sixteenth.

There is now wide agreement (see T riche \& M cK night, 2004) that the sixteenth century protestant logician Ramus (Pierre de la Ramée) is a major figure in the history of this traditional curriculum. This comes out forcibly in $\mathrm{D}$ avid $\mathrm{H}$ amilton's (1990) Curriculum H istory. Ramus' logic consisted of a branching scheme of dichotomies, expressed in print form as a series of conceptual maps, from the most general categories to the most specific, within which the heterogeneity of God's created world could be systematically ordered. Following Plato, Ramus held that this world was to be understood as a 'material counterpart of an ordered series of ideas existing in the mind of G od' (quoted in M organ, 1986, p. 107).

Ramus was, in $\mathrm{H}$ amilton's words (1990, p. 23), 'the high priest of method'. $\mathrm{H}$ is logical maps were about both what to teach and how to teach it ( p. 26). T hey enabled the content of learning to be systematically arranged in discrete branches of knowledge and sub-divided into smaller units within those; and they gave teachers clear routes through the material, moving from more abstract to less abstract, experiencerelated components and vice versa. It is easy to understand the attractiveness of Ramist method to Puritan preachers, schoolmasters and textbook writers in the late 
sixteenth and early seventeenth centuries, given the link that Puritans made between possessing knowledge of God's world and personal salvation and their consequent interest in transmitting to their audiences huge quantities of orthodox information rather than encouraging them to think for themselves. Ramist thinking was not only important in the development of Puritan education in England and Scotland. It was also central to $\mathrm{N}$ ew England Puritanism in America (M iller, 1939, chapter 5); and on the continent of Europe found its clearest educational expression in the work of Jan Comenius (T riche \& M cK night, 2004, p. 53).

By the eighteenth century, while most élite education in B ritain was still confined to the classics, the Puritan-rooted, dissenting communities in England and in Scotland were developing systems of schooling for older boys based on a broad curriculum of discrete subjects taught in English-a curriculum in which more abstract subjects took precedence. These subjects typically included logic, ethics, theology, mathematics, branches of science (then known as 'natural philosophy') and sometimes aspects of history and geography.

The D issenting A cademies, founded in England for the theological training as well as, in some cases, the general education of sons of dissenters after the Clarendon Code of the early 1660 s debarred them from much of public life, have often been credited with the introduction of the 'modern' curriculum (M CLachlan, 1931; Clarke, 1940, p. 16; Williams, 1961, pp. 133-134); but it seems that their influence may have been more limited than once thought (M ercer, 2001). We need to add to their work that of the Scottish 'academies' of the eighteenth century, rooted in the Presbyterian culture of that country, which also provided a broad-based initiation into the major forms of knowledge of the day (Strong, 1909, pp. 161-169)

$T$ he role of the $D$ issenting Academies in the scientific advances which helped to turn England into an industrial country is well known, the chemist Joseph Priestley, for instance, having being a tutor at Warrington A cademy. $\mathrm{H}$ ow is it that these and other institutions set up by the most earnest of protestant $\mathrm{C}$ hristians, the descendants of the Puritans, could have devoted so much of their energy to the sciences and to the mathematics behind them?

F or the dissenters, including under this heading the Scottish Presbyterians, there was no conflict. The most important thing in their lives was personal salvation-of themselves and their families first and then of other members of their community. A condition of election was a sound and comprehensive understanding of God's creation in all its heterogeneity. $\mathrm{H}$ ence the importance in the academies of the new 'modern' subjects which replaced the traditional classical curriculum of the grammar schools and universities. Although some of these were harnessable to non-salvationist goals, both personal and industrial, until well on into the eighteenth century they were not studied primarily for those reasons. The central focus was on the acquisition of various kinds of knowledge for its own sake, given its significance as a prerequisite of salvation.

M organ's (1944) study of the Puritan family in seventeenth century N ew England underlines the attachment to acquiring knowledge which powered English and Scottish Puritans as well as N ew English Congregationalists. He writes: 
For a people who believed in predestination and the absolute sovereignty of God the Puritans ascribed an extraordinary power to education. (M organ, 1944, p. 51)

Parents had a duty to educate their children so that they, too, could become members of the 'elect' worthy of salvation. In particular, parents had to help their sons to choose their particular calling. (F or girls there was no choice since their calling was to be a housewife.) Some boys, who were intelligent enough and whose parents were rich enough, might put off the choice of a calling until later by going to $\mathrm{H}$ arvard College.

Anyone with a 'liberal' education would adopt a 'liberal' calling, that is, a calling which required no manual labor and no long period of apprenticeship' (M organ, 1944, p. 30)

Parents wanted their children to 'do well' (p. 49), and had only fulfilled their obligations after they saw 'their Children well dispos'd of, well settled in the World' (quoted on p. 39), that is, well married and settled in their own home.

$C$ hildren learned to read and to acquire knowledge for religious reasons. As Protestants, they had to be able to read the Bible themselves (pp. 45-46). Lack of knowledge was seen as man's chief enemy-a reaction to the perceived intention of the old Roman C atholic regime to keep people ignorant. F or the Puritan the acquisition of knowledge, especially of the scriptures, was a necessary route to salvation (p. 46). T hey thought it should begin early and intensively. N ew England ministers believed that:

Satan never hesitated to begin his assaults upon children in their infancy, 'and therefore if you would prevent him, do not you delay, but be dropping in instruction as they are able, and as soon as they are able to understand any thing'. (M organ, 1944, p. 53)

'C hildren were taught as fast as they could learn' (ibid.).

One reason for the preoccupation with early learning must have been the far greater probability than in our age of dying young. Given the comparative recentness of the assumption that most people in our society will live into old age, this thought must have exercised devout parents even into the twentieth century. Comenius (see above), who, like M organ's $\mathrm{N}$ ew England families, lived in the seventeenth century, put forward as the first of his six reasons for beginning education early:

... the uncertainty of our present life. For that we must leave it is certain, but when and
how is uncertain. And that any should be snatched away unprepared is a danger greatly
to be dreaded, since a man is thus doomed eternally. For, just as a man must go through
life without a limb if he leave his mother's womb bereft of it, so, if, when we leave this
world, our minds have not been moulded to the knowledge of and participation in G od,
there will be no further opportunity given us. And therefore, as the matter is of such
importance, the greatest haste is necessary, lest any man be lost. (Comenius, 1907, p. 57)

M organ's account helps us to grasp the role that the acquisition of knowledge must have had for the abler sons of the more affluent English and Scottish dissenters of the eighteenth century, who went to the new academies and were the counterparts of those who received their 'liberal education' at $\mathrm{H}$ arvard College. K nowledge-acquisition was pursued with intensity, driven on by the work ethic to which the Puritans/ dissenters adhered. 
The central point for present purposes is that for most of the eighteenth century inducting academy students into the various disciplines of knowledge had a mainly religious purpose-to acquaint them with the manifold glory of God's world. The purpose of the curriculum was not primarily vocational or economic. This was a broad liberal education based largely on the pursuit of knowledge and orientated towards salvation.

There is more to be said about the origins of the dissenters' curriculum, but I want to look now at its posthumous influence. The new subject-based curriculum, the methodical pedagogy and rigid timetabling that went with it were favoured by the 'middling class' of persons, largely constituted by dissenters, who defined themselves against the landed establishment above and the poor below. Their religiosity, as T awney (1926) and others have taught us, brought them not only the conviction of salvation, but also worldly success. $\mathrm{H}$ ard work in dedication to a vocation chosen in line with God-given talents-often in commerce, banking or manufacture- paid off in financial terms.

By the early nineteenth century, the E nglish D issenting Academies were in decline as institutions of general education. At the same time new schools (private, proprietary and reformed grammar) were being created for the wealthy dissenting middle classes, who were now merging at the top end with the old establishment. Their clients pressed for the same kind of broad curriculum as had been found in the academies, in opposition to the narrow classical education of the old grammar schools. Brian Simon (1960, pp. 102-125) gives a good account of these developments.

The onward progress of the middle classes in wealth and now political influence continued through the nineteenth century, fuelled now by the evangelical revival, and facilitated by the repeal of the laws excluding dissenters from public life. Soon after mid-century, official action was taken to tidy up the raggedness of what schools across the nation were offering, and to fit the content of the curriculum explicitly to a threefold social class division. In the late 1850s and1860s, while the Clarendon Commission pressed for the retention of the classical curriculum in the leading public schools, and the $\mathrm{N}$ ewcastle Commission urged a three-Rs based education for the masses, the T aunton Commission recommended the general modern curriculum for second and third grade endowed and private schools, that is, largely for middle and lower ranks of the middle classes. The modern curriculum of the Prussian Realschule influenced its thinking, as did the curricular desires of different sections of the English middle classes. It is significant that Prussia was a Protestant state (its $L$ utheran and $\mathrm{C}$ alvinist churches had been brought together in a unified Evangelical Church in 1817) and that its modern curriculum in the Realschule had been created in line with the wishes of the same commercial and industrial groups as were central to the English middle class-who had been pressing governments for many years but with little success to improve schooling for their children along modern lines.

The twentieth century entrenched the middle classes- now much more diverse in their composition, increasingly secular after mid-century, and less separable from other social groups-in the political influence which they were beginning to attain by its early years. (T he 1906 election returned $185 \mathrm{~N}$ onconformist M Ps, nearly all 
sympathetic to the new Liberal government; see Binfield, 1977, p. 207.) The old Puritan notion of belonging to an elect destined for salvation had by then lost most of its force, but vestiges of it may have remained in the notion of an academic élite identified by mechanisms of selection. There were three decisive events here, spread evenly across those hundred years. Each of them involved what came increasingly to be seen as the 'traditional' subject-based curriculum.

In 1904 a chasm was created between the new local authority secondary schools and elementary schools. The secondary schools, as under the T aunton proposals about the content of schooling (which were not put into effect), had to follow a broad subject-based curriculum, consisting in the 1904 case of:

English language and literature, at least one language other than English, geography, history, mathematics, science, drawing, manual instruction (boys), domestic subjects ( girls), physical exercise and organised games.

Elementary schools, catering for some $75 \%$ of children, were obliged to follow a less intellectual curriculum, which included no science (only nature study), no foreign language and more manual subjects. The architect of this division at the Board of E ducation was a lapsed evangelical with an ancient Puritan pedigree, Robert $M$ orant (Allen, 1934, pp. 3-4). $\mathrm{H}$ is educational changes reflected his more general political conviction:

... of the increasing need of voluntarily subjecting the impulses of the many ignorant to the guidance and control of the few wise. (op cit., p. 125)

The second reinforcement of middle class power via education is found in the increasing use of intelligence tests to justify secondary selection, culminating in their post-Second World War use as part of the new $11+$ examination. A key figure here was C yril Burt, like M orant from Puritan (Congregationalist) stock (White, 2005, forthcoming). Burt was able to provide the system created by $M$ orant with a rationale based on the IQ and deriving ultimately from his eugenicist interest in preserving an intellectual élite. $\mathrm{He}$ held that if middle class children were over-represented in the new post-war grammar schools, this was because the higher average intelligence of parents tended to be transmitted to their children (Burt, 1969, p. 20). T he 1904 division between an academic curriculum for selective schools and a non-academic one for the rest was prolonged into the post-1944 era until the (partial) erosions of the new comprehensive system.

The third reinforcement was the introduction of the $\mathrm{N}$ ational Curriculum in 1988. As Richard Aldrich (1988, p. 22) has pointed out, the new statutory subjects were almost identical to those of 1904 . N ow they were for all children at state schools, not only a tiny élite. The subject-based curriculum was also extended from the secondary to primary schools. What began in the eighteenth century as a university/upper secondary level curriculum had percolated by 1988 into the infant school. ('D o not you delay, but be dropping in instruction as they are able, and as soon as they are able to understand any thing'. (See above p. 135)) The imposition of the middle-class curriculum on the whole nation did no disfavour to the middle classes. 


\section{Philosophical Legitimation}

The 1960s philosophies of education came soon after the second of these developments, the 1944 changes. They can be read as providing philosophical justifications for an improved form of the by now firmly entrenched subject-based curriculumnot as a middle class preserve but as an entitlement for all children. In the 1970s and 1980s they had a marked effect on official thinking about the curriculum, not least among $\mathrm{H}$ er $\mathrm{M}$ ajesty's Inspectorate ( $\mathrm{HMI}$ ), and may for this reason have had some influence on the shape taken by the $\mathrm{N}$ ational C urriculum in 1988.

Peters and $\mathrm{H}$ irst, in particular, both distanced their conception of education/ liberal education from instrumental, e.g., vocational, aims. Students were to engage in intellectual study not in order to get a good job but, in Peters's case, for its own sake (Peters, 1966, chapter 5); and in Hirst's, because of the connexion he made between the pursuit of propositional knowledge and the good life: a liberal education is 'the freeing of the mind to achieve its own good in knowledge' (H irst, 1965b, p. 43). This exclusion of utilitarian aims had a long pedigree, going back to the eighteenth century academies and beyond.

To the Calvinists the earth and the rest of the cosmos was G od's creation and therefore the study of it was in itself an act of reverence. (M ercer, 2001, p. 42)

$\mathrm{N}$ one of this is to deny more worldly motivations behind the modern subjectbased curriculum, either in the late eighteenth century or in the 1960s. By 1780, science was beginning to be seen as important within the academies for reasons of social status. In England the richer dissenters were beginning to merge with the old establishment.

To the socially élite, and those striving to achieve this status, science was seen as part of enlightenment culture. (ibid.)

In the Taunton Report of 1868, 'practical use in business', 'the value of culture in itself', and 'the advantage of sharing the education of the cultivated classes' all figure as reasons why core middle-class parents wanted a modern curriculum ( $\mathrm{M}$ aclure, 1965, p. 94). In the 1960s, parents also saw a broad intellectual education-the fare of the new grammar school but not the secondary modern- partly as the passport to a new meritocratic élite.

From the late eighteenth century until 2000, therefore, we find a Janus-faced curriculum - one side looking to the non-utilitarian aims advocated by institutions, and the other to the often extrinsic goals of their clientele. Official reaffirmations of the traditional curriculum from $\mathrm{M}$ orant to $\mathrm{T}$ hatcher have presented it not as useful for this or that purpose, but as something whose value is unquestioned. This is especially clear in the $1988 \mathrm{~N}$ ational Curriculum with its almost total absence of aims.

This paper has argued that, from the perspective of the early twenty-first century, the 1960s philosophies of the curriculum built around the demarcation of intellectual domains seem now to have been working within and unintentionally reinforcing the tradition of the 'modern' broad subject-based curriculum, which in the early 
twentieth century had won out over the classical curriculum in the wider battle for political supremacy between the old establishment and the aspiring middle classesa battle concluded by the merging of new and old élites in the interwar period (Rubinstein, 1998). After mid-century many egalitarian educational thinkers, including most or even all of the philosophers of education so far mentioned, wanted the working classes to enjoy the same curricular advantages as those from the elite. In some cases-as in my own-this desire was intensified by personal experience of upward social mobility via the 'ladder' of scholarships into elite schooling.

If this thesis is correct, the 1960s theories can be viewed as belonging to a long tradition of curriculum thinking in Britain, traceable back through the history of middle class education to the religiously-rooted curricula of the Puritan dissenters.

\section{Phenix and Peters}

The thesis is only about a way of seeing, an interpretation. It is not about intentions on anyone's part to provide a philosophical rationalisation for the recently victorious 'modern' curriculum over its rival, still less for the religious outlook which once lay behind it.

Given this disclaimer, there are religious considerations to do with the dissenting/ Puritan legacy which are worth airing when reviewing the work of the 1960s, although it is not clear how much weight should be placed on them. A good place to start is with Philip Phenix, whose work, although that of an American philosopher of the curriculum, became part of the standard syllabus on the topic in British higher education in the late 1960s and 1970s.

Phenix's well-known book Realms of M eaning (1964) discussed the ideal curriculum broadly as Paul $\mathrm{H}$ irst did-that is, in terms of a small number of logically distinct categories of understanding, not always by any means coincident with school subjects-although $\mathrm{H}$ irst erected his own categories on a different basis and independently of Phenix (H irst, 1974, chapter 4).

Phenix had a background in theology and university teaching in religion. $\mathrm{H}$ is religious views influenced his work in philosophy of education after his appointment to T eachers College in 1954. In Education and the Common G ood (1961) he wrote that 'the central task of education is religious conversion' (p. 242) and that:

... the sovereign test of all education is whether or not it is religious-that is, whether or not it tends towards conversion of the person to unconditional commitment to truth and right. (Phenix, 1961, p. 243)

The last quotation bears out Phenix's statement that he is understanding 'religious conversion' in a non-conventional sense (p. 242).

The word 'religious' is intended to signify the attitude and practice of sincere devotion to what is supremely worthful. ... We are reserving the name of religion in the present analysis for a reverential attitude to what is of ultimate value. (Phenix, 1961, p. 237)

This is the one supreme purpose which unites all the lesser purposes of education: to engender reverence. (Phenix, 1961, p. 252) 
Phenix's attachment to reverence puts us in mind of the old academies of the dissenters, the close connexion they made between the teaching of science and other subjects and awe at $\mathrm{G}$ od's created universe. $\mathrm{H}$ is theological education was at $\mathrm{U}$ nion Theological Seminary in N ew Y ork-the institution where the Congregationalist G. Stanley Hall had studied in the 1860s. He thus belonged to the same thoughtworld as that of the British dissenters.

Three years after Education and the Common Good, Phenix published his most well-known book Realms of M eaning (1964). It was here that he spelt out his abstract schema for the curriculum, based on the following six 'realms': symbolics, empirics, esthetics, synnoetics, ethics and synoptics. The close connexion between religion and the whole of education made in his earlier book is now absent, religion being confined to one of three strands belonging to 'synoptics', along with history and philosophy. We are told that 'the goal of the religious life is salvation' (p. 250). It looks as if the term 'religion' is being used here more in its conventional sense than in the 1961 book. At the same time, the overarching view that education has to do with exploring the different ways in which human life is connected to a larger whole of ultimate value connects the two works. The first words of Realms of $M$ eaning are:

It is not easy to sustain a sense of the whole. $M$ any a person pursues his own limited calling with scarcely a thought for his place in the total drama of civilised endeavour. (Phenix, 1964, p. 3)

And a little later he writes:

Students and teachers alike are prone to take the curriculum as they find it, as a traditional sequence of separate elements, without ever inquiring into the comprehensive pattern within which the parts are located. (ibid.)

This last quotation is revealing in its assumption that the traditional curriculum does have an overall meaning, but that it has come to be taken as a collection of disparate items. How far can Phenix be seen as reviving something of the old vision which guided the Puritan/dissenting curriculum but which had by the 1960s been largely eroded?

Phenix's emphasis on reverence, mentioned earlier, reminds us of the link Peters made a few years later between education and intrinsically worthwhile activities. $\mathrm{H}$ is transcendental argument for these is indeed couched partly in religious terms. In rejecting games in favour of theoretical activities as candidates for worthwhileness, he notes that they are 'hived off from man's curiosity about the world and his awe and concern about his own peculiar predicament within it', filling this out by a quotation from $W$ hitehead about the nature of religion and its connexion with the value of a human life in merging 'its individual claim with that of the objective universe' (Peters, 1966, p. 164). As Ray Elliott (1986) has written, Peters's:

... response to Being-in-totality and to human being-in-the-world, on the contemplation of them, is one of piety ... he attaches what is, according to his own account, a religious significance to that which gives and discovers meaning and which receives and discloses it. (Elliott, 1986, p. 57) 
When he wrote the passage mentioned above, Peters had been a convert to Q uakerism for some 30 years. How far does the transcendental argument contain echoes of the old belief, especially strong in Dissent, that, given the divine nature of the human soul, understanding oneself as situated in a world of which one stands in awe, is the route to understanding God and thereby the meaningfulness of our human life?

\section{Hirst and Dewey}

Unlike Phenix's and Peters's work, Paul Hirst's (1974b, first published 1965) account of a liberal education based on logically distinct forms of knowledge has no vestige of a religious rationale- not even anything so brief as Peters's hint in that direction in his transcendental argument. On H irst's view, religious knowledge (on the possibility of whose existence he cast serious doubt) may at most feature as one form of knowledge along with mathematics and other disciplines, but has no wider place in the curriculum. M ore generally, he makes it plain that while the autonomously acquired knowledge which underpins a Christian education is within a religious framework, in a secular education such as he favours this framework is not present:

It is true that the Christian sees education in a particular setting that is expressed in his religious beliefs. T his setting, of course, the non-C hristian does not share, but it makes no difference to the actual determination of the content and methods of education in general. Like scientific theory, educational theory is in general autonomous, and thus must be formed and justified independently of any religious beliefs a man may have. But of course in both of these the $C$ hristian regards the understanding he achieves as knowledge of $\mathrm{G}$ od's universe, which in $\mathrm{H}$ is goodness $\mathrm{H}$ e wishes men to achieve. T he $\mathrm{C}$ hristian thus sees autonomously acquired knowledge in a wide comprehensive understanding of experience that is religious. But this context adds nothing to scientific knowledge, and I see no reason to assume that it significantly affects educational principles in general. Religious beliefs give an added significance to what ought to be done, but they do not in any way alter its validity, for this is rationally determined. (H irst, 1965, p. 53)

$\mathrm{H}$ irst's emphasis on rationally determined knowledge, on freeing individuals' minds so that they can come to an objective appreciation of how things are in different domains, may be interpreted as a reaction against the evangelical Christianity in which he had been brought up.

It is interesting to compare Paul $\mathrm{H}$ irst in this respect with John D ewey, who also rejected his religious, in his case Congregationalist, upbringing in favour of more secular perspectives. Dewey reacted against the clear-cut dualisms (cf. Ramist dichotomies) and subject-centredness of the curriculum thinking of his time, and pressed for schooling to be firmly rooted in practical activities. This comes out in $\mathrm{M} y$ Pedagogic C reed:

I believe, therefore, that the true center of correlation on the school subjects is not science, nor literature, nor history, nor geography, but the child's own social activities. (D ewey, 1897, Article III) 
Although Dewey nowhere, to my knowledge, mentions the $\mathrm{N}$ ew England Puritan tradition which lay behind the broad subject-based, curriculum which he was criticising, his rejection of this type of schooling is in line with his wider rejection of his native religion.

Similar statements, apparently obliquely critical of the tradition, especially its penchant towards abstract classifications, are found in Democracy and Education, which refers to:

... the feeling that knowledge is high and worthy in the degree in which it deals with ideal symbols instead of the concrete; the scorn of particulars except as they are deductively brought under a universal; the disregard for the body; the depreciation of arts and crafts as intellectual instrumentalities. (D ewey, 1916, p. 310)

And also states:

Under present conditions the scholastic method, for most persons, means a form of knowing which ... includes making distinctions, definitions, divisions and classifications for the mere sake of making them-with no objective in experience. ... The doctrine of formal discipline in education is the natural counterpart of the scholastic method.

(D ewey, 1916, p. 399)

$\mathrm{H}$ irst, in contrast to Dewey, did not in 1965 reject a curriculum based on propositional knowledge in favour of a curriculum of a more practical sort, revolving around social engagement; although this is very much the sort of theory he came later to adopt when he shifted the basis of the curriculum from forms of knowledge to 'social practices' (H irst, 1993b). What he did, in effect, in 1965 was to put a broad propositional-knowledge-orientated curriculum on what he saw as a secure logical foundation, and without any religious framework surrounding it. $\mathrm{H}$ is views were not finally detached from a way of thinking which made propositional knowledge central until the 1990s, when, like Dewey, he made the practical reasoning found in social practices the centrepiece of his thinking.

\section{Conclusion}

To sum up. The agenda for mainstream philosophy of the curriculum in the 1960s and early 1970s was set by the $\mathrm{H}$ irst-Peters approach with its emphasis on the pursuit of various kinds of propositional knowledge for non-instrumental reasons. In effect, if not in intention, their and the other theories mentioned helped to give the traditional subject-based curriculum (in an idealised form) a credibility which for those coming from other directions was hard to see. There is much room for thinking that the kind of curriculum all these philosophers favoured has its roots in what between 1860 and 1900 had come to be seen as a middle-class, 'modern' curriculum, and more deeply in the education of dissenting communities in the previous two centuries. (For a recent account of how aspects of contemporary curriculum thinking in the USA have their roots in the Puritanism of early $\mathrm{N}$ ew England and also in Ramist thinking, see McKnight, 2003.) There are also religious aspects, connected with dissenting outlooks, of the 1960s work, but it is 
not clear whether this fact is merely a curiosity of little consequence or whether it is more significant.

There is no good reason for basing curriculum planning centrally around school subjects or forms of knowledge. One must start further back, with a broad exploration of overall aims. From these and other considerations, logical, practical and empirical, one can derive sub-aims of increasing specificity. $M$ any of these aims will centre around or require different kinds of knowledge, among other things. At some point along the chain towards specificity, school subjects, or parts of them, may well have some role as vehicles of realising more general aims- but then other vehicles may well also have a role. (On all these points, see White, 1982, 1990; O'H ear \& White, 1991; H irst, 1993a).

All this has immediate practical relevance. The subject-based English $\mathrm{N}$ ational Curriculum is even harder to justify now that, since 2000 , there has been a reasonable set of overall aims to drive it. The mismatch between the new aims and the regulations for most of the traditional subjects is now very plain to see (White, 2003). Calls for aims-based rather than subject-based curricula are at last gathering force, not least within the Qualifications and C urriculum Authority (QCA), whose $2005 \mathrm{Futures}$ project (www.qca.org.uk/futures) is encouraging those responsible for different school subjects to reflect on the contribution their subject could make towards realising the overall aims.

\section{Notes on contributor}

John White is Emeritus Professor of Philosophy of Education at the Institute of Education $U$ niversity of $L$ ondon. $H$ is interests are in aspects of mental life and in interrelationships among educational aims and applications to school curricula. $\mathrm{H}$ is recent books include Do H oward $\mathrm{G}$ ardner's $\mathrm{M}$ ultiple Intelligences $\mathrm{Add}$ U p?, The Child's M ind, Rethinking the School Curriculum (Ed.) and The Curriculum and the Child (forthcoming).

\section{References}

Aldrich, R. (1988) The N ational Curriculum: an historical perspective. In D. Lawton \& C. C hitty (Eds) The $N$ ational C urriculum, L ondon, Institute of Education U niversity of L ondon.

Allen, B.M . (1934) Sir R obert M orant, L ondon, M acmillan.

Barrow, R. (1976) Common Sense and the Curriculum, London, Allen \& U nwin.

Binfield, C. (1977) So down to prayers: studies in English nonconformity1780-1920 (L ondon, D ent).

Burt, C.L. (1969) The mental differences between children, in: C.B. Cox \& A.E. D yson (Eds)

(1969) B lack Paper T wo (L ondon, The C ritical Quarterly Society).

Clarke, F . (1940) E ducation and social change: an E nglish interpretation (L ondon, The Sheldon Press).

Comenius, J. A. (1907) The great didactic (L ondon, Adam \& C harles Black).

Dearden, R.F. (1968) The philosophy of primary education (L ondon, R outledge $\&$ K egan Paul).

D ewey, J. (1897) M y pedagogic creed, The School J ournal, 54(3).

Dewey, J. (1916) Democracy and education (N ew Y ork, M acmillan).

Downie, R., Loudfoot, E. \& T elfer, E. (1974) Education and personal relationships (L ondon, M ethuen). 
Elliott, R.K . (1986) Richard Peters: a philosopher in the older style, in: D .E . C ooper (E d.) E ducation, values and mind (L ondon, R outledge \& K egan Paul).

H amilton, D . (1990) Curriculum history (G eelong, D eakin U niversity).

$\mathrm{H}$ ans, N . (1951) N ew trends in education in the eighteenth century (London, Routledge \& Kegan Paul).

H irst, P.H . (1965) C hristian and secular education, H ibbert J ournal, 63.

H irst, P.H . (1974a) K nowledge and the curriculum (L ondon, Routledge \& K egan Paul).

H irst, P.H . (1974b) Liberal education and the nature of knowledge, in: P.H . H irst, K nowledge and the curriculum ( $L$ ondon, R outledge \& K egan Paul).

H irst, P.H . (1993a) The foundations of the N ational Curriculum: why subjects?, in: P. O'H ear \& J. White ( $\mathrm{E}$ ds) A ssessing the national curriculum, (L ondon, Paul C hapman).

H irst, P.H . (1993b) Education, knowledge and practices, in: R. Barrow \& P. White (Eds) B eyond liberal education: essays in honour of Paul $\mathrm{H}$ irst (L ondon, Routledge).

H irst, P.H . \& Peters R.S. (1970) The logic of education (L ondon, R outledge \& K egan Paul).

M aclure, S. (1965) Educational documents: England and Wales, 1816 to the present day (London, M ethuen).

M cK night, D. (2003) Schooling, the Puritan imperative and the molding of an A merican national identity ( $M$ ahwah, N J, L awrence Erlbaum).

M CL achlan, H . (1931) English education under the T est A cts ( $M$ anchester, M anchester U niversity Press).

M ercer, M. (2001) Dissenting academies and the education of the laity, 1750-1850, $\mathrm{H}$ istory of E ducation, 30(1), 35-58.

M iller, P. (1939) The N ew England mind: the seventeenth century ( $N$ ew Y ork, M acmillan).

M organ, E.S. (1944) T he Puritan family (Boston, T rustees of the Public Library).

M organ, J. (1986) G odly learning: Puritan attitudes towards reason, learning and education, 1560-1640 (C ambridge, C ambridge U niversity Press).

O'H ear, P. \& White, J. (Eds) (1991) A national curriculum for all (London, Institute for Public Policy Research).

Peters, R.S. (1966) E thics and education (L ondon, Allen \& U nwin).

Phenix, P.H. (1961) E ducation and the common good (N ew Y ork, H arper).

Phenix, P.H . (1964) R ealms of meaning (N ew Y ork, M cG raw-H ill).

Rubinstein, W.D. (1998) Britain's élites in the interwar period, 1918-1939, in: A. Kidd \& D. N icholls (Eds) The making of the B ritish middle class? (Stroud, Sutton).

Simon, B. (1960) Studies in the history of education 1780-1870 (L ondon, L awrence \& W ishart).

Strong, J. (1909) A history of secondary education in Scotland (Oxford, Clarendon Press).

T awney, R.H . (1926) Religion and the rise of capitalism (West D rayton, Penguin).

Triche, S. \& M CK night, D. (2004) The quest for method: the legacy of Peter Ramus, H istory of Education, 33(1) 39-54.

White, J. (1973) T owards a compulsory curriculum (L ondon, Routledge \& K egan Paul).

White, J. (1982) The aims of education restated (L ondon, Routledge \& K egan Paul).

White, J. (1990) Education and the good life (L ondon, Kogan Page).

White, J. (2005) Puritan intelligence, Oxford Review of Education, 31(3),.

White, J. (forthcoming) Intelligence, destiny and education: the ideological roots of intelligence testing (L ondon, R outledge).

White, J. (Ed.) (2003) Rethinking the school curriculum (L ondon, RoutledgeF almer).

Williams, R. (1961) The long revolution (L ondon, C hatto \& Windus).

Young, M .F.D. (Ed.) (1971) K nowledge and control (London, C ollier-M acmillan). 